\title{
STOCK MARKET RETURNS AND EXCHANGE RATE MOVEMENTS IN A MULTIPLE CURRENCY ECONOMY: THE CASE OF ZIMBABWE
}

\author{
Mabutho Sibanda* \\ University of KwaZulu-Natal \\ sibandam@ukzn.ac.za
}

Received: June 2015

Accepted: October 2015

\begin{abstract}
This study seeks to provide new evidence on the stock market and exchange rate relationship in Zimbabwe, a country that does not have its own sovereign currency. The bivariate vector autoregressive approach is used to establish the relationship between the stock market and exchange rates. The results show that no relationship exists between the stock market and the proxy exchange rate. The findings contradict the expectation that exchange rate movements would influence domestic stock market prices. This finding is especially interesting given the fact that Zimbabwe uses a basket of currencies for transacting purposes, albeit with the United States dollar as a major currency for reporting and stock market pricing purposes. The findings provide new evidence of a disconnect between the stock market and exchange rate movements. This has implications for international portfolio diversification and the use of foreign currency as an asset class in an economy using a multiple currency system.
\end{abstract}

Keywords

Exchange rates; multiple currency; portfolio diversification; Zimbabwe Stock Exchange

*MrM Sibanda is a lecturer in the School of Accounting, Economics \& Finance, University of KwaZulu-Natal, South Africa. 


\section{INTRODUCTION}

The impact or reverse thereof of stock markets on exchange rates has received considerable attention in the literature over the past couple of decades. Numerous approaches have been used to establish such a relationship and results remain obscure, as they are based either on a specific country or bloc of economies. The stock market-exchange rate nexus discourse has continued to receive attention since the work of Dornbusch and Fischer (1980) on assets pricing and exchange rates. Existing studies either focus on individual countries' stock markets and exchange rates or empirically test several stock markets within trading blocs and how they relate to exchange rate movements. The typical study on the stock market and exchange rate relationship has been conducted in countries that manage their own foreign exchange rate systems. This study takes a different angle in that the relationship is tested based on a proxy exchange rate due to the multiple currency regime system adopted by Zimbabwe in 2009. In this study, a proxy exchange rate is used to represent the basket of currencies used as the medium of exchange in Zimbabwe.

Zimbabwe abandoned its currency in favour of the multiple currency system on 30 January 2009 (Mutengezanwa, Mauchi, Njanike, Matanga, \& Gopo, 2012) after experiencing close to a decade of economic and financial turmoil (Nakunyada \& Chikoko, 2013). After adopting a multiple currency system Zimbabwe has been using a basket of currencies that include the United States (US) dollar, South African rand, Botswana pula, euro and the pound sterling. However, the two main currencies used are the US dollar and the South African rand (Mutengezanwa et al., 2012; Pindiriri, 2012). The US dollar has been used as the currency for financial and fiscal reporting purposes (Pindiriri, 2012). Since the adoption of the multiple currency system coupled with reduced company productivity, Zimbabwe has relied on South Africa for imports (Nakunyada \& Chikoko, 2013; Pindiriri, 2012). Consequently, the US dollar/rand exchange rate is the main currency exposure facing Zimbabwean investors, firms and investors seeking international portfolio diversification. Zimbabwean firms and investors face currency risk, and hedging such risk is costly given that the behaviour of the exchange rate is not within the control of the country's monetary authorities (Brixiová \& Ncube, 2014).

Established in 1894 and once ranked second to South Africa in terms of market breadth and depth, the Zimbabwe Stock Exchange (ZSE) (Sibanda \& Holden, 2013) has had its successes and failures owing mainly to the performance of the political economy. The ZSE has two main indices, the industrial index and the mining index. The exchange has experienced a drop in the number of firms listed from 76 in 2010 to 58 in 2015. This decline in the number of listed companies is mainly due to suspensions and delisting arising mainly from viability issues (Rusvingo, 2014). However, investing on the Zimbabwean stock market could be taken as a currency hedge in a similar way as investing in US dollar-denominated stocks is. A currency hedge is similar to currency risk hedging where the ultimate goal is to minimise portfolio volatility (de Roon, Eiling, Gerard, \& Hillion, 2012). Stock prices on the stock exchange are quoted in US cents and company reporting is also in US dollars (Zimbabwe Stock Exchange, 2013). Since stock prices are quoted in US dollar terms, investing in such stocks should theoretically yield the same returns as would be achieved in investing in US dollar quoted stocks, implying the stock market can act as an effective haven for US dollar rate movements. This study therefore seeks to establish the relationship between the ZSE industrial index and the US dollar/rand exchange rate for a period spanning February 2009 to May 2015. The ZSE industrial index was rebased in February 2009 following the adoption of the multiple currency system. It is important to note that the ZSE halted trading at the peak of the hyperinflation period from August 2008 to January 2009 as the then Zimbabwean dollar depreciated tremendously in line with the then astronomically high inflation levels. 


\section{LITERATURE REVIEW}

Several studies have looked at the relationship between stock prices and exchange rates, albeit without reaching consensus regarding results. This has been particularly so in emerging market economies, where the influence of stock prices could be subjected to international macroeconomic factors (Gay Jr, 2011; Ehrmann, Fratzscher, \& Rigobon, 2011; Muhammad, Rasheed, \& Husain, 2002). The dynamic relationship between stock (assets) prices between two countries could also be a function of changes in the countries' exchange rates (Ehrmann et al., 2011; Dornbusch \& Fischer, 1980). Thus, if stock prices in two different countries move together then the stock price movements of these two countries could be influenced by these countries' exchange rate movements (Kisaka \& Mwasaru, 2012). The relationship between stock markets and exchange rates has been demonstrated using different methods, and results tend to vary accordingly. Cross-correlations between the stock market and exchange rate have been observed in China, for example, suggesting that the relationship varies with time and is dependent on reforms of the exchange regime (Cao, Xu, \& Cao, 2012).

A negative relationship between the stock market and exchange rates implies that increases in stock market prices lead to an appreciation in the real exchange rate (Moore \& Wang, 2014). However, in a country without its own currency this is intuitively different, as the exchange rate is determined outside the country's economic fundamentals. The relationship can be unidirectional from the stock market (exchange rate) to the exchange rate (stock market) or bidirectional (Liang, Chen, \& Yang, 2015). The relationship is, however, country specific and evidence from emerging markets shows that changes in the exchange rates causes changes in the stock prices (Liang et al., 2015; Gay Jr, 2011; Moore \& Wang, 2014). Interestingly, results differ even in advanced economies, with the US and United Kingdom (UK) providing evidence that suggests unidirectional causality from the stock market to the exchange rate showing the influence of the US and UK stock markets on exchange rate movements (Caporale, Hunter \& Ali, 2014). However, Caporale et al. (2014) also showed that Switzerland and the euro area demonstrated bidirectional causality, suggesting that stock market and exchange rate movements influence each other (Caporale et al., 2014). When using a long-run co-integration model, a long-run causal relationship from stock market to exchange rate has been observed in the European Union ( $\varepsilon U$ ), while only a short-run relationship existed in the US during the financial crisis of 2008-2012 (Tsagkanos \& Siriopoulos, 2013). The difference is attributed to the nature of economic and political connectivity in the $E U$ compared to the US (Tsagkanos \& Siriopoulos, 2013). This evidence clearly shows that the relationship between the stock market and exchange rates remains contemporary and relevant in asset diversification in that stock markets could be used to hedge against currency risk or simply both the stock market and foreign currency as standalone assets in a portfolio.

Transmission of shocks from one asset to another asset, a phenomenon known as contagion, tends to influence asset prices (Caccioli, Shrestha, Moore, \& Farmer, 2014). Consistent with contagion, stock market prices tend to exhibit co-movement traits with exchange rates, especially during periods of crises as compared to stable periods (Lin, 2012). This is in line with the stock-oriented models of exchange rate (Frenkel, 1987). However, the uncovered equity parity, a condition which asserts countries with stock markets that are expected to perform strongly should experience a currency depreciation, was tested in 43 countries and evidence showed no relationship between stock prices and exchange rates, suggesting that the two variables may not influence each other (Cenedese, Payne, Sarno, \& Valente, 2014). Although causality may exist (unidirectional or bidirectional), such relationships vary across time scales and frequency (Tiwari, Bhanja, Dar, \& 
Islam, 2015). Similarly, a study on the BRICS (Brazil, Russia, India, China, and South Africa) bloc confirms that stock markets tend to influence exchange rates in both turbulent and stable periods (Chkili \& Nguyen, 2014). Of the BRICS bloc, Chkili and Nguyen (2014) found that it is only in South Africa that the stock market returns do not impact on exchange rates, while exchange rates do not impact on the stock market returns in the entire bloc.

In international portfolio management, the total dollar return on an investment is calculated as a function of foreign currency return multiplied by current gain or loss (Shapiro, 2010). The appreciation of the domestic currency further influences capital flows and in particular portfolio investments by both private and public investors (Combes, Kinda, \& Plane, 2012). Portfolio flows are, however, more volatile than other capital flows such as remittances and foreign direct investments (Combes, Kinda, \& Plane, 2012; Jongwanich \& Kohpaiboon, 2013). It is therefore important to ascertain the relationship of the stock market and exchange rates in a country without its own currency. This relationship is essential in the understanding of asset allocation and risk hedging, hence portfolio diversification. A country without its own currency does not have monetary policy flexibility; hence interventions in the foreign exchange market by the central bank are limited (Brixiová \& Ncube, 2014). The next section describes the sources of data and the methodology used in this study.

\section{RESEARCH DESIGN}

The study uses the ZSE industrial index and US dollar/rand exchange rate spanning from February 2009 to May 2015. Monthly data on each series is obtained on the last trading day of the month to avoid survival bias and any adjustments to the data. Monthly stock market returns are assumed to capture economic and business conditions in a country (Brooks, 2008). Observations over 74 months are obtained. The ZSE industrial index data is obtained from the ZSE, while the US dollar/rand exchange rate data is obtained from the South African Reserve Bank (SARB) website. US dollar/rand exchange rate data is obtained as rand/US dollar exchange rates, and these rates are converted into direct quotation taking the US dollar as home to Zimbabwe. The exchange rate is quoted as midpoints obtained by SARB from banks in South Africa (South African Reserve Bank, 2015). Nominal exchange rates are used instead of real exchange rates. However, the fact that Zimbabwe does not influence the currency through its monetary and fiscal interventions means that using real exchange rates is not possible. The US dollar / South African rand exchange is used as a surrogate exchange rate to represent a basket of currencies being used in Zimbabwe (multiple currencies). Zimbabwe adopted the US dollar as the reporting and official transacting currency in 2009 (Nakunyada \& Chikoko, 2013). The exchange rate is chosen due to the fact that the US dollar is used as an official reporting currency and that South Africa is Zimbabwe's major trading partner (in the form of imports into Zimbabwe) (Pindiriri, 2012).

Stock market returns are determined by using the ZSE industrial index returns (ZSE). Stock market returns represent average reward for investors who choose the equity investments as an asset class. Exchange rate gains/losses are calculated as returns on exchange rates ( $\varepsilon X)$. $\varepsilon X$ is measured as the dollar price of foreign currency where a negative value means the dollar has appreciated while a positive value means the dollar has depreciated against the South African rand. For both series, the returns are calculated as follows:

$$
R_{t}=\frac{P_{t}-P_{t-1}}{P_{t-1}}
$$


where $R_{t}$ the nominal is return of the ZSE ( $(\mathcal{X X})$ at month $t, P_{t}$ is the value of ZSE ( $\left.\varepsilon X\right)$ at month $t$, and $P_{t-1}$ is the value of the ZSE ( $\left.\varepsilon X\right)$ at the previous month.

This study adopts the short-run dynamics based on the bivariate vector autoregressive approach (VAR). VAR treats all variables as endogenous; hence there is no need to specify which variables are endogenous or exogenous (Brooks, 2008). In a bivariate VAR only two variables are used, and their current values depend of different combinations of the previous values of the two variables and error terms (Brooks, 2008). VAR further allows for the use of Granger causality tests. Granger causality tests will be used to test the relationship between stock prices and exchange rates. Thus the direction of causality will be the main aim of the Granger causality tests. The relationship can either be unidirectional or bidirectional. However, it is also possible to have no relationship at all. Stationarity tests are determined using the Augmented Dickey-Fuller (ADF) and the PhillipsPerron approaches to test the null hypothesis that the series are stationary (Agiakloglou \& Newbold, 1992; Dickey \& Fuller, 1981). Stationary series are defined 'as one with a constant mean, constant variance and constant autocovariances for each lag' (Brooks, 2008:318). The use of non-stationary data in time series analysis can lead to spurious regressions. The ADF is preferred in annual, quarterly and monthly time series over the Phillips-Perron tests (Dejong, Nankervis, Savin, \& Whiteman, 1992; Krämer, 1998). However, both tests are conducted to verify the rejection or failure of rejection of the null hypothesis that the series contain a unit root (Tsagkanos \& Siriopoulos, 2013). The following equations demonstrate how the ADF is conducted (Abdalla \& Murinde, 1997; Dickey \& Fuller, 1981; Enders, 2010):

$$
\begin{gathered}
\Delta Z S E=\alpha_{0}+\beta_{1} T+\varphi_{1} Z S E_{t-1}+\sum_{i=1}^{n} \alpha_{i} \Delta Z S E_{t-1}+\varepsilon_{1 t} \\
\Delta E X=\alpha_{0}+\beta_{2} T+\varphi_{2} E X_{t-1}+\sum_{i=1}^{n} \emptyset_{i} \Delta E X_{t-1}+\varepsilon_{2 t}
\end{gathered}
$$

where $\Delta$ is first difference operator, hence $\triangle Z S E=Z S E_{t}-Z S E_{t-1}$ and $\Delta E X=E X_{t}-E X_{t-1} ; \alpha, \beta_{1}, \beta_{2}$, $\varphi_{1}, \varphi_{2}, \alpha_{i}, \emptyset_{i}$ are coefficients; $T=$ time trend; $\varepsilon_{1 t}$ and $\varepsilon_{2 t}$ are white noise errors. The null hypothesis is that $Z S E_{t}$ and $E X_{t}$ have unit roots, i.e. $H_{0}=\varphi_{1},=\varphi_{2}=1$. If the null hypothesis is rejected then the series are said to be integrated of order zero, i.e. I (0) and VAR at levels will be conducted to test the short-run relationship between the two series (Tsagkanos \& Siriopoulos, 2013; Enders, 2010; Brooks, 2008). However, failure to reject the null hypothesis means the series will be first differenced (Enders, 2010). The failure to reject the null hypothesis suggests that the series is non-stationary and use of such data could lead to spurious regression output. If the null hypothesis that the series contain a unit root after first differencing is not rejected, then the series will be integrated of order one, i.e. I (1) and VAR at first differences will be conducted (Brooks, 2008). In this case, the series is said to be stationary at first differencing and can be used in the regression analysis. One condition of the use of VAR is that the series be stationary either at levels or first differences (Brooks, 2008).

Lag selection criteria used are the $\mathrm{R}^{2}$ as the Schwartz-Bayes Information criterion and Akaike's information criterion (AIC), which produced conflicting outcomes. The maximum lag length used is 2 lags. A bivariate VAR where two variables, ZSE and $E X$, are used as follows:

$$
\begin{gathered}
Z S E_{t}=\beta_{10}+\beta_{11} Z S E_{t-1}+\alpha_{11} E X_{t-1}+\mu_{1 t} \\
E X_{t}=\beta_{20}+\beta_{21} E X_{t-1}+\alpha_{21} Z S E_{t-1}+\mu_{2 t}
\end{gathered}
$$


where $u_{1 t}$ is a white noise disturbance term with $\varepsilon\left(u_{i t}\right)=0,(i=1,2), \varepsilon\left(u_{1 t} u_{2 t}\right)=0$ (Brooks, Introductory Econometrics for Finance, 2008). Given the fact that Zimbabwe is using other countries' currencies and the fact that its economy is negligible compared to the owners of the currencies, this study expects a unidirectional causality from the US dollar/rand exchange rate to the ZSE.

\section{DISCUSSION}

The ZSE industrial index and US dollar/rand exchange rate have a correlation coefficient of 0.53982 , suggesting that the two series move together, although the relationship is not that strong. The correlation coefficient is statistically significant at all levels of significance, suggesting that there is a linear relationship between the index and the exchange rate. TABLE 1 provides descriptive statistics for the two series.

\section{TABLE 1: Descriptive statistics (2009-2015)}

\begin{tabular}{lcc}
\hline & ZSE Industrial Index & US\$ /Rand \\
\hline Mean & 0.017209078 & -0.00202 \\
Standard Error & 0.011024581 & 0.003514 \\
Median & 0.004511114 & -0.00085 \\
Standard Deviation & 0.094837031 & 0.030226 \\
Sample Variance & 0.008994063 & 0.000914 \\
Kurtosis & 9.419654627 & 1.781654 \\
Skewness & 2.514637851 & 0.662449 \\
Range & 0.612223556 & 0.175403 \\
Minimum & -0.138578199 & -0.06726 \\
Maximum & 0.473645357 & 0.108139 \\
Sum & 1.273471808 & -0.14936 \\
\hline Observations & 74 & 74 \\
\hline Source:Authorscos &
\end{tabular}

Source: Author's computations. Data from SARB and ZSE websites

The descriptive statistics above shows the behaviour of the series during the period under review. A close analysis of the descriptive statistics shows that the ZSE Industrial Index series has some outliers, which could influence the mean and hence the large range value. After plotting the series on a graph, it is evident that the series values from February 2009 to April 2015 were inflated and characterised by instability. This was mainly due to the rebasing of the index upon the adoption of the multiple currency system in February 2009. As the economy moved from the use of the Zimbabwean dollar to the multiple currency system the market found it difficult to properly adjust the Zimbabwean dollar values to US dollar values, hence the series overshooting (Brogaard, Hendershott, \& Riordan, 2014). Researchers should therefore take caution when using the series starting from February 2009 to April 2015. 
The average return on the ZSE Industrial Index was $1.7 \%$ per month, with a standard deviation of $9.5 \%$ over the six-year period. On the other hand, the mean return on the US dollar/rand exchange rate was negative $0.2 \%$, with a standard deviation of $3.0 \%$. The Augmented Dickey-Fuller and Phillips-Perron tests for unit roots in the series are used for both the ZSE Index and the US dollar/rand exchange rate. Stationarity and unit root tests results are presented in TABLE 2.

\section{TABLE 2: Unit root tests}

\begin{tabular}{|c|c|c|c|}
\hline \multicolumn{2}{|c|}{ Augmented Dickey-Fuller test statistic } & $\mathrm{t}$-Statistic & Prob.* \\
\hline \multicolumn{2}{|c|}{ US\$/Rand exchange rate } & -7.017145 & 0.0000 \\
\hline \multicolumn{2}{|l|}{ ZSE Industrial Index } & -9.446470 & 0.0000 \\
\hline \multicolumn{4}{|c|}{ Phillips-Perron test statistic } \\
\hline \multicolumn{2}{|c|}{ US\$/Rand exchange rate } & -6.982033 & 0.0000 \\
\hline \multicolumn{2}{|l|}{ ZSE Industrial Index } & -9.446470 & 0.0000 \\
\hline \multirow[t]{3}{*}{ Test critical values: } & $1 \%$ level & -4.092547 & \\
\hline & $5 \%$ level & -3.474363 & \\
\hline & $10 \%$ level & -3.164499 & \\
\hline
\end{tabular}

Source: Author's computations

*MacKinnon (1996) one-sided $p$-values

Both approaches test the null hypothesis that the series has a unit root. The null hypothesis that the series has a unit root is rejected in favour of the alternative hypothesis. This suggests that the series is integrated of order I ( 0 ), thus eliminating the possibility of a co-integrating relationship between the two series. The use of a nominal exchange rate is expected to lead to short-run dynamics as suggested in the literature (Chinn, 2006), hence a non-cointegrating relationship. The VAR model is applied to the series to establish the existence of short-run relationships. The condition for the use of VAR is that both series be stationary at levels or first differences (Johansen, 1988). Thus the series is stationary at levels and meets the requirements of the use of the VAR methodology. TABLE 3 shows the output from the VAR model depicting the relationship between exchange rates and the Zimbabwe stock market.

The VAR results show that despite the two series being integrated of order I ( 0 ), there is no Granger causality running in either direction of the US dollar/rand exchange rate and the ZSE Industrial Index. However, the US dollar/rand exchange rate is influenced by its past returns, while the ZSE Industrial Index is influenced by its past returns in the second month. In line with existing evidence (Moore \& Wang, 2014), a negative relationship between the exchange rate and the stock market is observed, although it is statistically insignificant at all conventional levels of significance. 
TABLE 3: Short-run dynamics between the US Dollar/Rand and ZSE industrial index

\begin{tabular}{ccc}
\hline US\$_RAND $(-1)$ & US\$_RAND & ZSE \\
& 0.304529 & 0.119034 \\
US\$_RAND(-2) & $(0.12515)$ & $(0.30197)$ \\
& -0.065986 & 0.426982 \\
ZSE(-1) & $(0.12582)$ & $(0.30359)$ \\
ZSE(-2) & -0.078520 & -0.034176 \\
\hline C & $(0.05051)$ & $(0.12187)$ \\
& 0.013418 & -0.205475 \\
\hline & $(0.04269)$ & $(0.10300)$ \\
\hline
\end{tabular}

Source: Author's computations

Figures in bold statistically significant at $5 \%$ level

In spite of the adoption of a stable currency as a reporting and transacting currency, the ZSE is not realising the benefits accruing to such stability. The use of the US dollar for transacting purposes makes the Zimbabwean goods and stocks more expensive relative to other countries as the dollar appreciates against other currencies. For instance, investors in South Africa would have to spend more South African rands to buy one unit of foreign currency (US dollar), making dollardominated assets expensive in relative terms. However, international investors who already have US dollar-denominated assets in Zimbabwe could sell (translate) them and realise (accrue) higher foreign currency exchange gains.

The Pairwise Granger Causality tests in TABLE 4 further demonstrate the non-existence of a relationship between the US dollar/rand exchange rate and the ZSE Industrial Index.

TABLE 4: Pairwise Granger Causality tests

\begin{tabular}{lccc}
\hline Null Hypothesis: & Obs & F-Statistic & Prob. \\
ZSE does not Granger Cause US\$_RAND & 70 & 1.22875 & 0.2994 \\
US\$_RAND does not Granger Cause ZSE & & 1.34810 & 0.2669 \\
\hline
\end{tabular}

Source: Author's computations

The null hypothesis that the US dollar/rand exchange rate does not Granger Cause ZSE is not rejected at all conventional levels of significance. Consequently, the expectation that the ZSE is influenced by changes in the exchange rate is not upheld.

Although some studies have demonstrated a unidirectional causality from the exchange rate to the stock market (Caporale et al., 2014), others show a unidirectional causality from the stock market to the exchange rate (Liang et al., 2015; Chkili \& Nguyen, 2014), and a few show bidirectional causality (Cenedese et al., 2014; Tsagkanos \& Siriopoulos, 2013; Caporale et al., 2014). This study shows that no relationship exists between the stock market returns and 
exchange rates in the multiple currency set up in Zimbabwe. The results from this study fail to prove any previous empirical evidence on the relationship between stock markets and exchange rates mainly due to the use of a proxy exchange rate and the unavailability of a domestic sovereign currency for the stock exchange in question.

\section{CONCLUSION}

This study provides new evidence on the exchange rates-stock market return with its primary focus on a country without a sovereign currency. In an ideal economy with a sovereign currency, the relationship between stock market returns and exchange rates displays either a unidirectional causality from the stock market to the exchange rate or vice versa. However, the literature shows that some economies experience bidirectional causality between stock market returns and exchange rates. The relationship between the two series can either be determined through the use of short-run dynamic models, such as VAR, or long-run co-integration models, such as error correction models. Using the VAR technique, this study finds no relationship between the stock market index and exchange rates in a multiple currency system. A proxy exchange rate based on the official reporting currency and the major currency of imports is used, and reveals that the exchange rate series and the stock market index have no short-run and long-run relationships despite the two series being integrated of order zero I ( 0 ). This has implications for economic integration and international portfolio diversification. The implications for economic integration are that the Zimbabwean economy could be influenced by the South African economic activity and the latter's exchange rate regime; portfolio diversification in that foreign currency and stocks could be used as independent or complementary assets in a portfolio, since the two do not move in tandem. Consequently, the US dollar (used as a proxy currency) / South African rand exchange rate and the stock market can be used as an independent asset class, thus providing portfolio diversification benefits to investors. Portfolio diversification allows investors to minimise portfolio risk and enhance returns in spite of economic cycles. However, the stock market cannot be used as a currency hedge in a multiple currency economy, as the exchange rate and stock market movements are not related.

\section{LIST OF REFERENCES}

Abdalla, I. S., \& Murinde, V. (1997). Exchange rate and stock price interactions in emerging financial markets: evidence on India, Korea, Pakistan and the Philippines. Applied financial Economics, 7(1), 25-35.

Agiakloglou, C., \& Newbold, P. (1992). Empirical Evidence on Dickey-Fuller-Type Tests. Journal of Time Series Analysis, 13(6), 471-483.

Brixiová, Z., \& Ncube, M. (2014). The Real Exchange Rate and Growth in Zimbabwe: Does the Currency Regime Matter? IZA Discussion Papers, No. 8398, 1-29.

Brogaard, J., Hendershott, T., \& Riordan, R. (2014). High-frequency trading and price discovery. Review of Financial Studies, 27(8), 2267-2306.

Brooks, C. (2008). Introductory Econometrics for Finance, $2^{\text {nd }}$ edition. New York: Cambridge University Press. 
Caccioli, F., Shrestha, M., Moore, C., \& Farmer, J. D. (2014). Stability analysis of financial contagion due to overlapping portfolios. Journal of Banking \& Finance, 46, 233-245.

Cao, G., Xu, L., \& Cao, J. (2012). Multifractal detrended cross-correlations between the Chinese exchange market and stock market. Physica A: Statistical Mechanics and its Applications, 391 (20), $4855-4866$.

Caporale, G. M., Hunter, J., \& Ali, F. M. (2014). On the linkages between stock prices and exchange rates: Evidence from the banking crisis of 2007-2010. International Review of Financial Analysis, 33, 87-103.

Cenedese, G., Payne, R., Sarno, L., \& Valente, G. (2014). What Do Stock Markets Tell Us About Exchange Rates? Available at SSRN 2467707.

Chinn, M. D. (2006). Real exchange rates. New Palgrave Dictionary.

Chkili, W., \& Nguyen, D. K. (2014). Exchange rate movements and stock market returns in a regimeswitching environment: Evidence for BRICS countries. Research in International Business and Finance, 31, 46-56.

Colacito, R., \& Croce, M. M. (2011). Risks for the long-run and the real exchange rate. Journal of Political Economy, 119(1), 1-33.

Combes, J. L., Kinda, T., \& Plane, P. (2012). Capital flows, exchange rate flexibility, and the real exchange rate. Journal of Macroeconomics, 34(4), 1034-1043.

De Roon, F., Eiling, E., Gerard, B., \& Hillion, P. (2012, October 17). Currency Risk Hedging: No Free Lunch. Retrieved October 19, 2015, from SSRN: http://ssrn.com/abstract=1343644 or http://dx.doi.org/10.2139/ssrn. 1343644

DeJong, D. N., Nankervis, J. C., Savin, N. E., \& Whiteman, C. H. (1992). The power problems of unit root test in time series with autoregressive errors. Journal of Econometrics, 53(1), 323-343.

Dickey, D. A., \& Fuller, W. A. (1981). Likelihood Ratio Statistics for Autoregressive Time Series with a Unit. Root. Econometrica, 49, 1057-1072.

Dornbusch, R. (1976). Expectations and Exchange Rate Dynamics. Journal of Political Economy, 84, 1161-1176.

Dornbusch, R., \& Fischer, S. (. (1980). Exchange rates and the current account. The American Economic Review, 960-971.

Ehrmann, M., Fratzscher, M., \& Rigobon, R. (2011). Stocks, bonds, money markets and exchange rates: measuring international financial transmission. Journal of Applied Econometrics, 26(6), 948-974.

Enders, W. (2010). Applied Econometric Time Series, $3^{\text {td }}$ edition. USA: Wiley \& Sons, Inc.

Frankel, J. A. (1987). Monetary and portfolio-balance models of exchange rate determination. University of California, Berkeley, Department of Economics.

Frankel, J. (1986). Expectations and Commodity Price Dynamics: The Overshooting Model. American Journal of Agricultural Economics, 68, 344-348.

Gay Jr, R. D. (2011). Effect of macroeconomic variables on stock market returns for four emerging economies: Brazil, Russia, India, and China. International Business \& Economics Research Journal, 7(3), 1-8.

Johansen, S. (1988). Statistical analysis of cointegration vectors. Journal of Economic Dynamics and Control, 12(2), 231-254. 
Johansen, S., \& Juselius, K. (2001). Controlling inflation in a cointegrated vector autoregressive model with an application to US data. University of Copenhagen Dept. of Economics Discussion Paper, 01-03.

Jongwanich, J., \& Kohpaiboon, A. (2013). Capital flows and real exchange rates in emerging Asian countries. Journal of Asian Economics, 24, 138-146.

Jorion, P. (1991). The pricing of exchange rate risk in the stock market. Journal of Financial and Quantitative Analysis, 26(3), 363-376.

Kisaka, S. E., \& Mwasaru, A. (2012). The causal relationship between exchange rates and stock prices in Kenya. Research Journal of Finance and Accounting, 3(7), 121-130.

Krämer, W. (1998). Fractional integration and the augmented Dickey-Fuller test. Economics Letters, 61(3), 269-272.

Liang, C. C., Chen, M. Y., \& Yang, C. H. (2015). The Interactions of Stock Prices and Exchange Rates in the ASEAN-5 Countries: New Evidence Using a Bootstrap Panel Granger Causality Approach. Global Economic Review, D01:10.1080/1226508X.2015.1035300(Published online: 44 Apr 2015), 1-11.

Lin, C. H. (2012). The co-movement between exchange rates and stock prices in the Asian emerging markets. International Review of Economics \& Finance, 22(1), 161-17.

Moore, T., \& Wang, P. (2014). Dynamic linkage between real exchange rates and stock prices: Evidence from developed and emerging Asian markets. International Review of Economics \& Finance, 39, 1-11.

Muhammad, N., Rasheed, A., \& Husain, F. (2002). Stock Prices and Exchange Rates: Are they related? Evidence from South Asian Countries. The Pakistan Development Review, 41(4), 535-550.

Mutengezanwa, M., Mauchi, F. N., Njanike, K., Matanga, J., \& Gopo, R. N. (2012). The possibility of reintroducing the Zimbabwean dollar. Australian Journal of Business and Management Research, 2(6), $1-8$.

Nakunyada, W. \& Chikoko, L. (2013). The competitiveness of Zimbabwe's exports to South Africa during the recovery period 2009 to 2011 . Journal of Economic and Financial Sciences, 6(3), 645-660.

Pindiriri, C. (2012). Monetary Reforms and Inflation Dynamics in Zimbabwe. International Research Journal of Finance and Economics, (90), 207-222.

Rusvingo, S. (2014). Decline in business activity on the Zimbabwe Stock Exchange. A sign of a blood path on the Zimbabwean economy. Global Journal of Management and Business Research, 14(9), 3238.

Shapiro, A. (2010). Multinational Financial Management, $9^{\text {th }}$ edition. Asia: John Wiley \& Sons, Inc.

Sibanda, M., \& Holden, M. (2013). Stock market development and economic growth in the SADC region: Evidence from seven selected countries. PULA: Botswana Journal of African Studies, 27(49), 292-307.

South African Reserve Bank. (2015). South African Reserve Bank. Available: https://www.resbank.co.za/ (Accessed 3 June 2015)

Tiwari, A. K., Bhanja, N., Dar, A. B., \& Islam, F. (2015). Time-frequency relationship between share prices and exchange rates in India: Evidence from continuous wavelets. Empirical Economics, 48, 699-714. 
Tsagkanos, A., \& Siriopoulos, C. (2013). A long-run relationship between stock price index and exchange rate: a structural nonparametric cointegrating regression approach. Journal of International Financial Markets, Institutions and Money, 25, 106-118.

Welch, L. (1974). Lower bounds on the maximum cross correlation of signals. IEEE Transactions on Information Theory, 397-399.

Zimbabwe Stock Exchange. (2013). Available: http://www.zimbabwe-stockexchange.com/about/about-us/. (Accessed 20 May 2015) 